Sharif University of Technology
Scientia Iranica
SCIENTIA
I RAN ICA

\title{
A 3D polyoxoniobate-based framework showing performance in dye removal from aqueous solution
}

\author{
B. Safarkoopayeh ${ }^{\mathrm{a}}$ A. Abbasi ${ }^{\mathrm{a}, *}$, A.H. Mokarizadeh ${ }^{\mathrm{b}}$, A. Shayesteh $^{\mathrm{a}}$, \\ and M. Najafi ${ }^{\mathrm{a}}$ \\ a. School of Chemistry, College of Science, University of Tehran, Tehran, P.O. Box 14155-6455, Iran. \\ b. School of Chemical Engineering, University of Tehran, Tehran, P.O. Box 1417466191, Iran. \\ Received 26 December 2018; received in revised form 31 August 2019; accepted 7 October 2019
}

\section{KEYWORDS \\ Polyoxoniobate; Dye removal; \\ X-ray structure; \\ Water pollutant; \\ DFT calculations; \\ QTAIM.}

\begin{abstract}
A polyoxoniobate-based 3D framework $\left[\mathrm{K}_{8} \mathrm{H}_{30} \mathrm{Nb}_{6} \mathrm{O}_{31}\right]$ (1) was prepared through a hydrothermal method and characterized by single crystal X-ray diffraction, Powder X-Ray Diffraction (PXRD), solid state UV-visible, and thermogravimetric analysis (TGA). Structure and properties of $\mathbf{1}$ were investigated by various computational methods. Quantum Theory of Atoms in Molecules (QTAIM) and NBO studies together with thermogravimetric analysis suggest the existence of strong interactions among potassium ion, Lindqvist hexaniobate, and water molecules. Hirshfeld surfaces around the $\mathrm{Nb}_{6} \mathrm{O}_{19}^{8-}$ reveal that the Lindqvist ion acts as a $\eta^{3}$ ligand for the alkali cations. One remarkable detail about the structure is the presence of an encaged potassium ion, surrounded by six water molecules and four potassium ions. The prepared polyoxoniobate (PONb) was tested in the removal of diazo dye pollutant in water. The result shows that $\mathbf{1}$ has good activity and stability during the dye removal process and can be recovered and reused at least for five cycles.
\end{abstract}

(C) 2019 Sharif University of Technology. All rights reserved.

\section{Introduction}

During the past few decades, global environmental pollution has become one of the most serious topics. Many industries such as textile, cosmetics, leather, and plastic expel many toxic and carcinogenic organic compounds that seriously pollute water [1-7]. Among such pollutants, organic dyes have a great influence on photosynthetic activity in aquatic biota and, thus, the

\footnotetext{
*. Corresponding author. Tel.: +982161113644; Fax: +982166495291

E-mail addresses: Barzin.kupayeh@ut.ac.ir (B. Safarkoopayeh); a_abbasi@ut.ac.ir (A. Abbasi); mokarizadeh.hadi@gmail.com (A.H. Mokarizadeh); ashayesteh@ut.ac.ir (A. Shayesteh); mnajafi2014@yahoo.com (M.Najafi)
}

doi: $10.24200 /$ sci. 2019.52548 .2770 treatment of dye wastewater is of critical importance to modern societies.

Removal of dye pollutants by degradation is generally challenging due to the intrinsic stability of these compounds towards light and oxidation reactions [810]. Various methods including physical, chemical, and biological approaches have been investigated for dye wastewater treatment [11-13]. Physical methods such as adsorption, ion-exchange, or liquid-liquid extraction have proven to be ineffective towards pollutants, since they are easily transferred to other organic pollutants, leading to secondary pollution. Biological methods, on the other hand, suffer from several limitations including high-cost equipment and low degradation rates $[14,15]$.

On the contrary, Advanced Oxidation Process (AOP) that uses highly reactive radicals, such as hydroxyl radical and $\mathrm{O}_{2}^{-}$, offers excellent pathways for the degradation of organic dye pollutants in water. 
This process, however, has its own disadvantages and requires low $\mathrm{pH}$ and UV light [16-19]. Therefore, investigations into more efficient catalytic systems are of critical importance to find practical solutions to this problem. Owing to their ferroelectric, piezoelectric, and photocatalytic properties, niobate powders have recently attracted tremendous attention [20-25]. Polyoxoniobates [26-32] and other polyoxometalates [33-40] have also proved to be efficient catalysts for numerous reactions such as water oxidation, dye degradation, chemical warfare degradation, Knoevenagel condensation, and alcohol epoxidation.

In the present study, obtained findings on the synthesis and characterization of a novel polyoxoniobatebased 3D framework $\left[\mathrm{K}_{8} \mathrm{H}_{30} \mathrm{Nb}_{6} \mathrm{O}_{31}\right]$ (1), prepared by hydrothermal method, are reported. Removal of Bismarck brown as a representative of dye pollutants is investigated in water and under mild conditions. Furthermore, this study performs calculations for determining relative geometric structures, Bond Order (B.O.), electron density, and other properties of the 3D framework using DFT calculations, QTAIM, NBO, and reduced density gradient.

\section{Experimental}

\subsection{Materials and methods}

All chemicals were purchased from commercial sources and used as received. Bismarck brown was obtained from Sigma. The PXRD patterns were recorded using a Philips diffractometer with $\mathrm{Cu} \mathrm{K}_{\alpha}$ radiation ( $\left.K_{\alpha}=1.5406 \AA\right)$. The FT-IR spectra were acquired on a Bruker Equinox 55 spectrometer equipped with a single reflection diamond ATR system. The UV-Vis spectra were obtained using a Perkin Elmer Lambda 850 spectrophotometer.

\subsection{Synthesis of $\mathrm{K}_{8} \mathrm{H}_{30} \mathrm{Nb}_{6} \mathrm{O}_{31}$}

An aqueous solution $(12 \mathrm{~mL})$ containing $4.8 \mathrm{~g}$ potassium hydroxide and $2.65 \mathrm{~g} \mathrm{Nb}_{2} \mathrm{O}_{5}$ was poured into a $23 \mathrm{~mL}$ Teflon-lined stainless-steel autoclave. The autoclave was sealed and heated in an oven at $200^{\circ} \mathrm{C}$ for $24 \mathrm{~h}$ and, then, cooled to room temperature at a rate of $12.5^{\circ} \mathrm{C} / \mathrm{h}$. Colorless block crystals suitable for X-ray structural analysis were isolated by filtration, washed with distilled water, and dried at ambient temperature.

\subsection{Synthesis of $\mathrm{K}_{6} \mathrm{H}_{2} \mathrm{Nb}_{6} \mathrm{O}_{19} .13 \mathrm{H}_{2} \mathrm{O}$ Salt}

$\mathrm{K}_{6} \mathrm{H}_{2} \mathrm{Nb}_{6} \mathrm{O}_{19} \cdot 13 \mathrm{H}_{2} \mathrm{O}$ salt was synthesized using the method proposed by Cavaleiro et al. In the typical synthesis, $30 \mathrm{~mL}$ aqueous solutions of $\mathrm{KOH}: \mathrm{Nb}_{2} \mathrm{O}_{5}$ (60:1 ratio) were heated at $200^{\circ} \mathrm{C}$ for $24 \mathrm{~h}$. To the obtained solution, an equivalent volume of absolute ethanol was added and the precipitated solid was filtered, washed with cold water-ethanol (50\%), and dried at ambient temperature [41].

\subsection{Single crystal X-ray diffraction}

X-ray data for the titled compound were collected on Marresearch $345 \mathrm{dtb}$ diffractometer using Mo $\mathrm{K}_{\alpha}$ radiation $(\lambda=0.71073 \AA)$ at $295 \mathrm{~K}$. The structure was solved by direct methods using SHELXS-97, and the obtained model was refined with SHELXL-97 [42]. All non-hydrogen atoms were refined anisotropically. Hydrogen atoms were added at ideal positions and refined using a riding model.

\subsection{Dye removal procedure}

In a typical procedure for the degradation of Bismarck brown, $30 \mathrm{mg}$ of $\mathbf{1}$ was suspended in a fresh aqueous dye solution $\left(C_{0}=0.5 \mathrm{~g} / \mathrm{L}, 100 \mathrm{~mL}\right)$, and the suspension was stirred at a given time under mild conditions. The samples were withdrawn periodically for UV-Vis analysis to investigate the color removal of the dye at $457 \mathrm{~nm}$. Dye removal was then calculated according to the following equation:

$$
\text { Color removal }(\%)=\left[\left(A_{0}-A\right) / A_{0}\right] \times 100,
$$

where $A_{0}$ and $A$ are the initial and final absorbance values of the dye, respectively.

\section{Computational details}

To get detailed insights into the electronic structure of $\mathbf{1}$, density functional theory calculations were done with the PBE0 functional [43] and the Def2-TZVP basis sets [44] using the ORCA 3.0.3 program [45]. The natural bond orbital analysis was performed using the GenNBO program, [46] and the bonding characteristics were analyzed by the quantum theory of atoms in molecules (QTAIM) and reduced density gradient with the Multiwfn 3.3.7 program [47].

\section{Results and discussion}

\subsection{Structure of $\mathrm{K}_{8} \mathrm{H}_{30} \mathrm{Nb}_{6} \mathrm{O}_{31}$}

Crystallographic parameters of $\mathbf{1}$ are given in Table 1. As seen in Figure 1, the asymmetric unit of this compound comprises $\left[\mathrm{Nb}_{4} \mathrm{O}_{12}\right]^{4-}$, seven $\mathrm{K}^{+}$, and nine water molecules. The polyoxoniobate (PONb) cluster contains six $\mathrm{Nb}$ centres with octahedral geometry. Four types of $\mathrm{O}$ atoms exist in $\mathbf{1}$ including terminal $\left(\mathrm{O}_{t}\right)$, bridging $\left(\mathrm{O}_{b}\right)$, and two kinds of central $\mathrm{O}\left(\mathrm{O}_{c}\right)$. Three types of $\mathrm{Nb}^{-\mathrm{O}_{t}}$ are observed in the $\mathrm{PONb}$ in which $\mathrm{O}$ atom is connected to one, two, or three $\mathrm{K}^{+}$ions, respectively. The bond length ranges for $\mathrm{Nb}-\mathrm{O}$ are presented in Table 2. Three $\mathrm{K}^{+}$ions are bonded to the bridge oxygens ( $\mathrm{O} 6, \mathrm{O} 5$, and $\mathrm{O} 2$ ), while the rest of $\mathrm{K}^{+}$ions are connected to $\mathrm{O}_{t}$ atoms.

There are hydrogen bonding interactions between water molecules and $\mathrm{O}$ atoms of the PONb clusters (Figure 2(a)). Some of these interactions are shown in Table 3. The $\mathrm{Nb}_{6} \mathrm{O}_{19}^{8-}$ anions are linked together 
Table 1. Crystal and structure refinement data for $\mathbf{1}$.

\begin{tabular}{ll}
\hline Compound & \\
\hline Empirical formula & $\mathrm{K}_{8} \mathrm{H}_{30} \mathrm{Nb}_{6} \mathrm{O}_{31}$ \\
Molecular weight & 1396.50 \\
Crystal system & Orthorhombic \\
Space group & $\mathrm{P} n m a$ \\
Temperature $(\mathrm{K})$ & $293(2)$ \\
$a(\AA)$ & $23.996(5) \AA$ \\
$b(\AA)$ & $10.085(2) \AA$ \\
$c(\AA)$ & $13.008(3) \AA$ \\
$\alpha=\beta=\gamma\left(^{\circ}\right)$ & 90.00 \\
Cell volume $\left(\AA^{3}\right)$ & $3147.93(120) \AA^{3}$ \\
$\mathrm{Z}$ & 4 \\
$\rho(\mathrm{g}$ cm & \\
$\mu($ mm & -1 \\
Total reflections & 2.947 \\
Unique reflections & 3.279 \\
Observed reflections $\left[F^{2}>2 \sigma\left(F^{2}\right)\right]$ & 2744 \\
Data/restraints/parameters & $3053 / 35 / 290$ \\
Goodness-of-fit $(\mathrm{GOF})$ on $F^{2}$ & 1.114 \\
$R\left[F^{2}>2 \sigma\left(F^{2}\right)\right]\left(R_{1}, w R_{2}\right)$ & $0.0714,0.1833$ \\
$R($ all data $)\left(R_{1}, w R_{2}\right)$ & $0.0787,0.1890$ \\
\hline
\end{tabular}

through potassium cations and water molecules forming the 3D framework, depicted in Figure 2(b).

\subsection{Molecular structure}

Geometry optimization of $\mathrm{Nb}_{6} \mathrm{O}_{19}^{8-}$ began with initial atomic coordinates from the single crystal X-ray structure. Optimized bond lengths and bond angles of $\mathbf{1}$ are

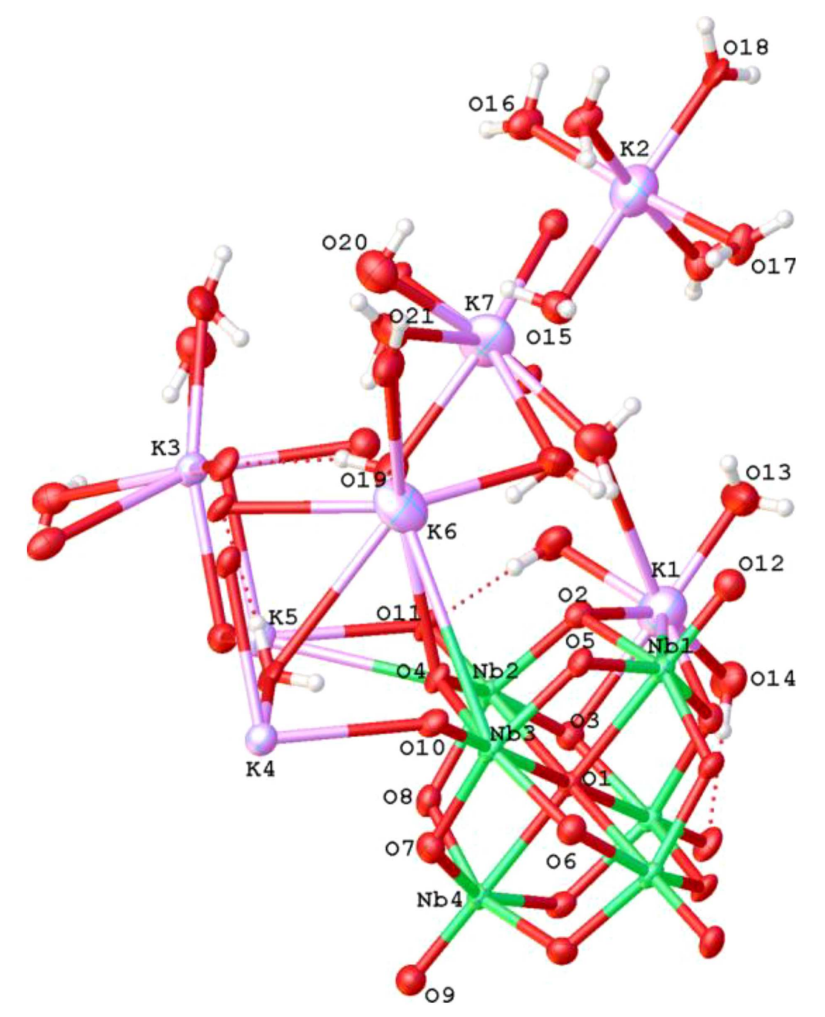

Figure 1. ORTEP diagram of $\mathbf{1}$.

listed in Table 4. All bond lengths and angels are in good agreement with the experimental data obtained through single crystal X-ray diffraction. Maximum deviations of the calculated bond lengths and bond angles from the experimental data are $0.10 \AA\left(\mathrm{Nb}-\mathrm{O}_{t}\right)$ and $3.0^{\circ}\left(\mathrm{Nb}-\mathrm{O}_{b}-\mathrm{Nb}\right)$. These deviations originate from the strong interaction of $\mathrm{O}_{t}$ and $\mathrm{O}_{b}$ with potassium cations in the solid phase structure. For the optimization of encaged potassium ion and Lindqvist ion with its surrounding atoms, the X-ray experimental atomic

Table 2. Bond length range in 1.

\begin{tabular}{|c|c|c|}
\hline & Bond & Bond length range $(\AA)$ \\
\hline $\mathrm{Nb}-\mathrm{O}_{t}$ & $(t$ : terminal $\mathrm{O}$; bonded to one $\mathrm{Nb}$ ) & $1.749(11)-1.805(7)$ \\
\hline $\mathrm{Nb}-\mathrm{O}_{b}$ & ( $b$ : bridging $\mathrm{O}$; bonded to two $\mathrm{Nb}$ ) & $1.991(7)-2.020(7)$ \\
\hline $\mathrm{Nb}-\mathrm{O}_{c 1}$ & $(c:$ central $\mathrm{O}$; bonded to six $\mathrm{Nb}$ ) & $2.359(6)-2.428(9)$ \\
\hline $\mathrm{Nb}-\mathrm{O}_{c 2}$ & $\left(c:\right.$ central $\mathrm{O}$; bonded to two $\mathrm{Nb}$ and one/two $\left.\mathrm{K}^{+}\right)$ & $2.006(6)-1.999(7)$ \\
\hline
\end{tabular}

Table 3. Hydrogen bonding interactions in $\mathbf{1}$.

\begin{tabular}{cccccc}
\hline DH...A & D...A & D-H & H...A & $<$ D-H-A & Symm. code \\
\hline O14H14A...O11 & $2.874(12)$ & $0.85(9)$ & $2.02(10)$ & $175(14)$ & $x, 3 / 2-y, z$ \\
O19H19A...O11 & $2.750(12)$ & $0.85(10)$ & $1.94(10)$ & $159(11)$ & $x, y, z$ \\
O15H15A...O3 & $2.680(16)$ & $0.85(5)$ & $1.84(4)$ & $167(18)$ & $1 / 2-x, 1-y,-1 / 2+z$ \\
O13H13B...O10 & $2.710(12)$ & $0.86(14)$ & $1.93(14)$ & $150(16)$ & $1 / 2-x, 1-y, 1 / 2+z$ \\
\hline
\end{tabular}




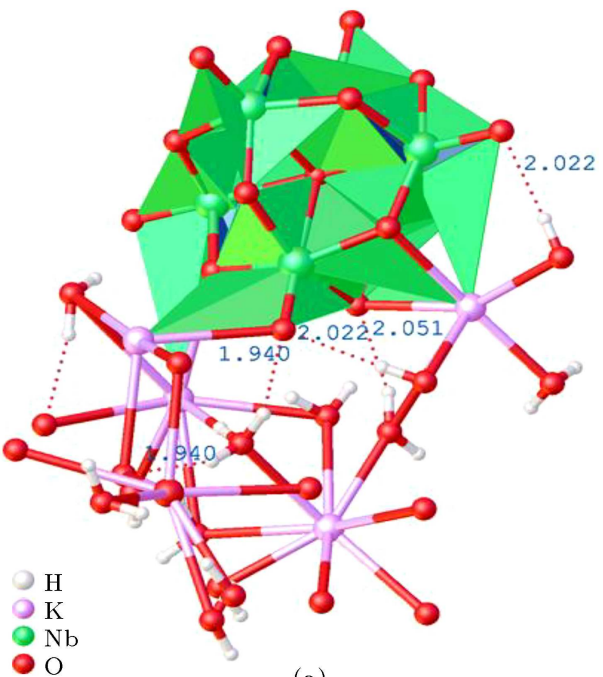

(a)

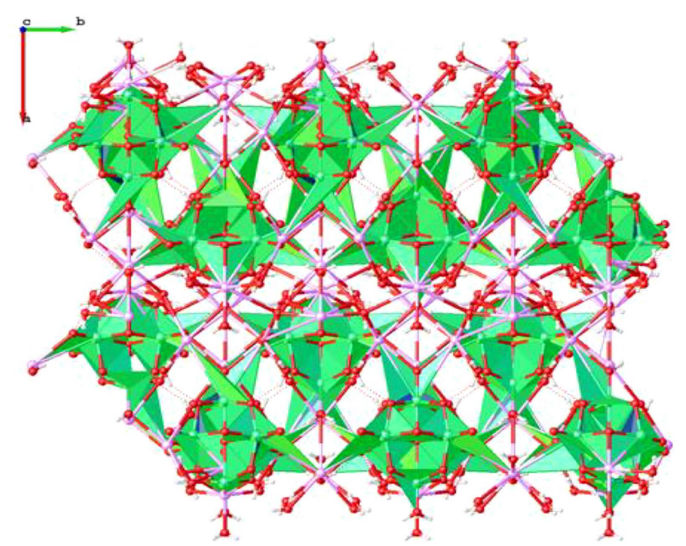

(b)

Figure 2. (a) hydrogen bonding interactions. (b) Packing in $\mathbf{1 .}$

Table 4. Selected bond lengths and angles in $\mathbf{1}$

\begin{tabular}{ccc}
\hline Bond & Experimental $(\AA)$ & Optimized $(\AA)$ \\
\hline $\mathrm{Nb} \mathrm{O}_{c}$ & $2.36(1)$ & 2.41 \\
$\mathrm{Nb}_{-} \mathrm{O}_{b}$ & $1.99(1)$ & 2.00 \\
$\mathrm{Nb}-\mathrm{O}_{t}$ & 1.76 & 1.86 \\
\hline Angels & Experimental & Optimized \\
\hline $\mathrm{Nb}-\mathrm{O}_{c}-\mathrm{Nb}$ & $179.8(4)$ & 179.82 \\
$\mathrm{Nb}-\mathrm{O}_{b}-\mathrm{Nb}$ & $113.6(3)$ & 117.14 \\
$\mathrm{Nb}_{-} \mathrm{O}_{b}-\mathrm{Nb}$ & $114.6(3)$ & 117.63 \\
$\mathrm{O}_{t}-\mathrm{Nb}-\mathrm{O}_{b}$ & $102.2(3)$ & 103.46 \\
$\mathrm{O}_{t}-\mathrm{Nb}-\mathrm{O}_{b}$ & $104.3(8)$ & 104.01 \\
\hline
\end{tabular}

coordinates were fixed and only the hydrogen atoms were optimized.

\subsection{Molecular crystal analysis with Hirshfeld surfaces}

In order to obtain deeper insights into intermolecular interactions in the molecular crystal, Hirshfeld surface [48-50] and the related 2D-fingerprint plot [51-53] were calculated by crystal explorer software [54]. Hirshfeld surface and the related 2D-fingerprint plots for the hexaniobate are shown in Figure 3. It can be seen that the most important interactions surrounding $\mathrm{Nb}_{6} \mathrm{O}_{19}^{8-}$ are $\mathrm{Nb} \ldots \mathrm{O} / \mathrm{O} \ldots \mathrm{Nb}(14.9 \%)$ and $\mathrm{K} \ldots \mathrm{O} / \mathrm{O} \ldots \mathrm{K}(24.7 \%)$ and appear as spikes in 2D fingerprint plots.

The investigation of Hirshfeld surfaces around $\mathrm{Nb}_{6} \mathrm{O}_{19}$ reveals that one of the favored bonding modes for potassium cations is on the face of the super octahedron and through three $\mathrm{K}^{+}-\mathrm{O}_{b}$ links; in other words, the Lindqvist ion acts as a $\eta^{3}$ ligand to the alkali cations. Another favored bonding mode is found to be bonding between terminal oxygen $\left(\mathrm{O}_{t}\right)$ and potassium cations (Figure 4).

Hirshfeld surface and the related 2D-Fingerprint plots for the encaged potassium ion are shown in Figure 5. The dominant interactions surrounding the encaged potassium are O...H/H...O/O (37.3\%) and $\mathrm{K} \ldots \mathrm{O} / \mathrm{O} \ldots \mathrm{K}(13.6 \%)$ and appear as spikes in $2 \mathrm{D}$ fingerprint plots. The red spot over the potassium ion confirms the presence of rather strong interactions between potassium cation and water molecules.

\subsection{QTAIM and reduced density gradient}

The most efficient method to analyze the electron density is Quantum Theory of Atoms In Molecules (QTAIM) [55,56]. It was used here to obtain a better insight into bonding characteristics in $\mathbf{1}$ and the encaged potassium ion in the molecular crystal. For this purpose, QTAIM and NBO calculations were performed on the packing structure of 1 (Figure 6) to provide a better understanding of the strength of intermolecular interactions in the solid structure. In addition, reduced density gradient analysis was performed on the encaged potassium to investigate the bonds in more detail [57]. QTAIM result shows considerable electron sharing between potassium ion and oxygen atoms in Lindqvist hexaniobate ion with the surrounding atoms. The results are summarized in Table 5 .

The Delocalization Indices (DI) for these bonds indicate considerable amounts of electron sharing between potassium ions and water molecules. The reduced density gradient analysis confirmed the presence of weak and moderate interactions in the encaged 


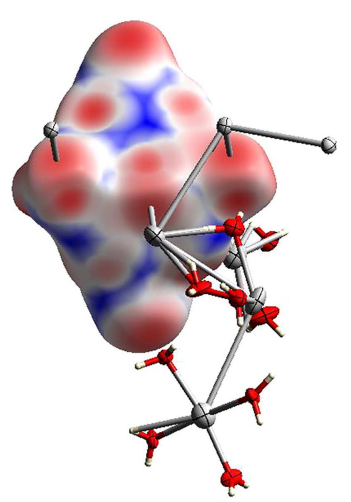

(a)

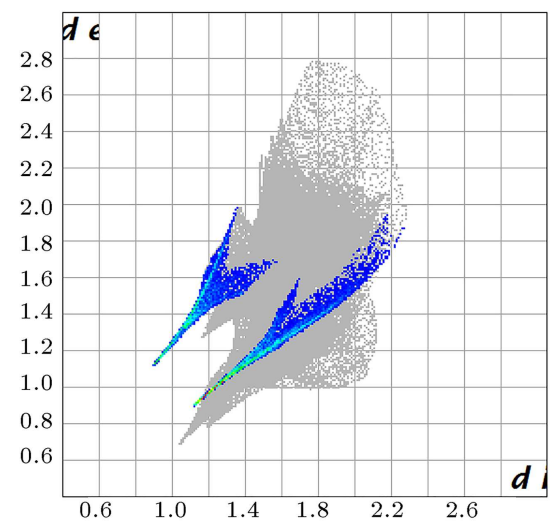

(c)

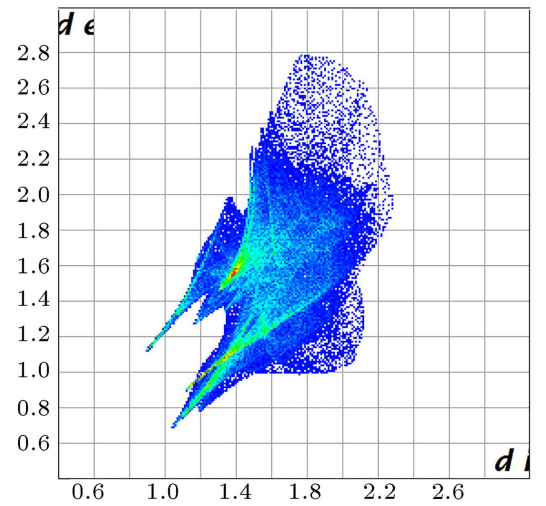

(b)

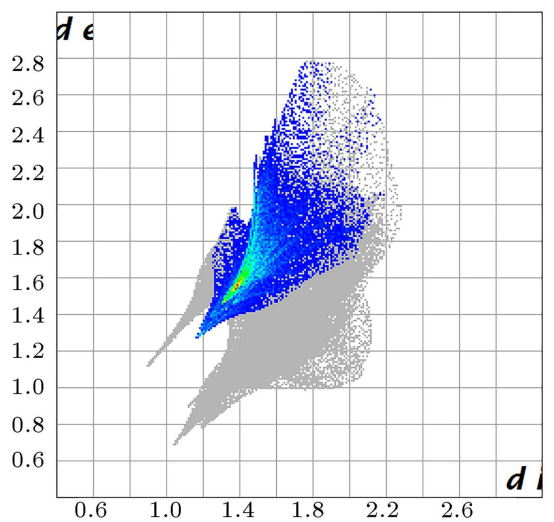

(d)

Figure 3. (a) Hirshfeld surfaces mapped with $d_{\text {norm }}$ for $\mathrm{Nb}_{6} \mathrm{O}_{19}$. (b) Respected fingerprint plot. (c) $\mathrm{Nb} \ldots \mathrm{O} / \mathrm{O} \ldots \mathrm{Nb}$ highlighted. (d) K...O/O...K highlighted.

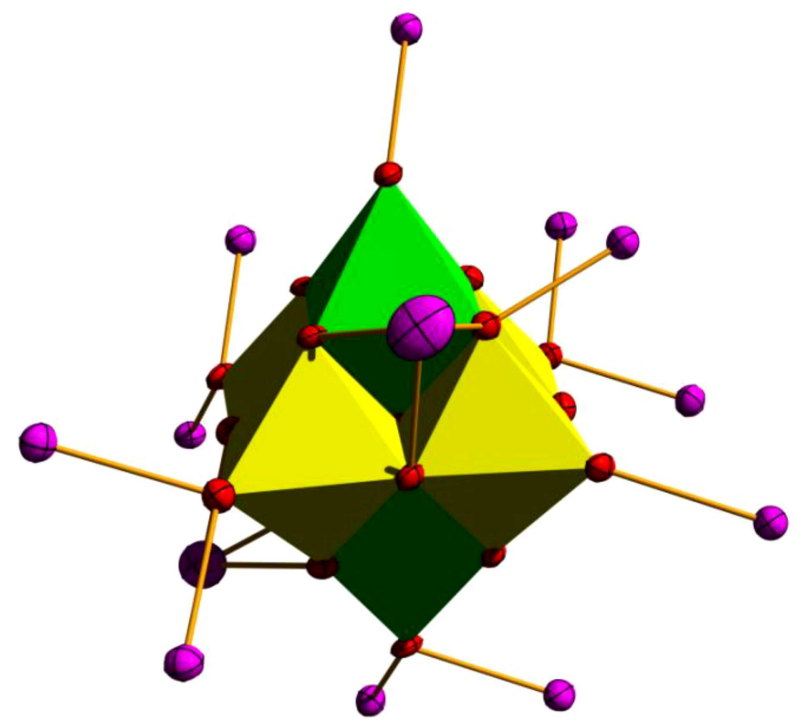

Figure 4. $\eta^{3}$ bonding mode of the super-octahedron cluster face to alkali cations.

potassium structure. The gradient isosurface for the encaged potassium is displayed in Figure 7.

\subsection{Natural bond orbitals}

The NBO method is used in order to understand the intra-molecular interaction of $\mathbf{1}$ and the encaged potassium and to complete the information obtained by QTAIM and reduced density gradient analysis. The calculated Mayer bond indices and natural atomic charges are given in Table 6 . NBO results of atomic charges agree with the calculated electrostatic potential map of $\left[\mathrm{Nb}_{6} \mathrm{O}_{19}\right]^{8-}$ (Figure $\mathrm{S} 1$ in Supplementary Information).

\subsection{Thermogravimetric analysis (TGA)}

The thermal properties of $\mathbf{1}$ were studied by TGA in the temperature range of $30-600^{\circ} \mathrm{C}$. TGA analysis of $\mathbf{1}$ is shown in Figure 8. The major weight loss up to $225^{\circ} \mathrm{C}$ was attributed to the decomposition of compound 1. It was found that the mass loss value of $16.17 \%$ was consistent with a calculated value of $15.47 \%$, which is attributed to crystalline water of compound 1.

\subsection{Spectroscopic studies}

Lindqvist hexaniobate exists in water as:

$$
\begin{aligned}
& {\left[\mathrm{H}_{3} \mathrm{Nb}_{6} \mathrm{O}_{19}\right]^{5-}, \quad\left[\mathrm{H}_{2} \mathrm{Nb}_{6} \mathrm{O}_{19}\right]^{6-},} \\
& {\left[\mathrm{HNb}_{6} \mathrm{O}_{19}\right]^{7-}, \text { and }\left[\mathrm{Nb}_{6} \mathrm{O}_{19}\right]^{8-},}
\end{aligned}
$$

at $\mathrm{pH}=8,10,12$, and 14 , respectively [58]. Solid state UV-visible spectrum of $\mathbf{1}$ and solution spectra of 


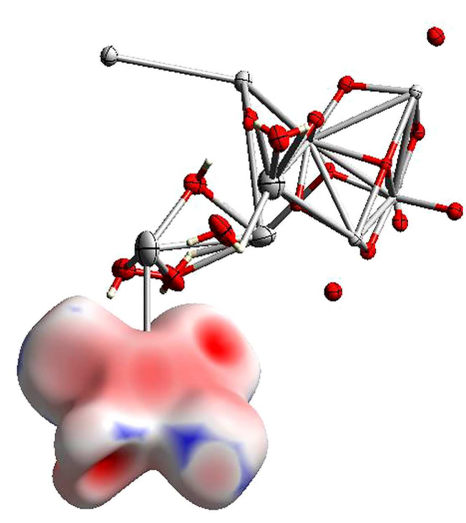

(a)

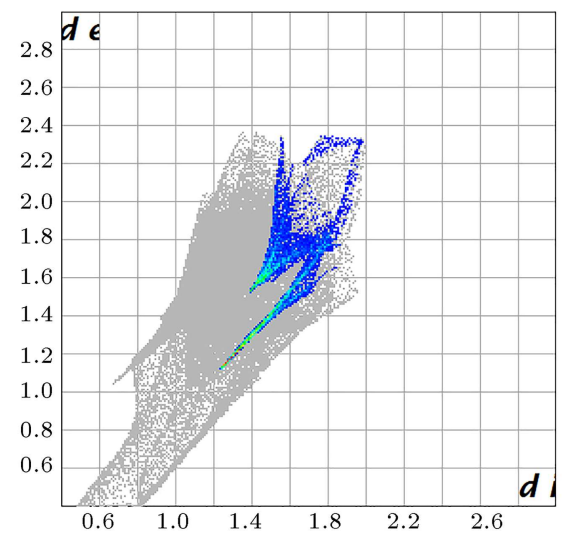

(c)

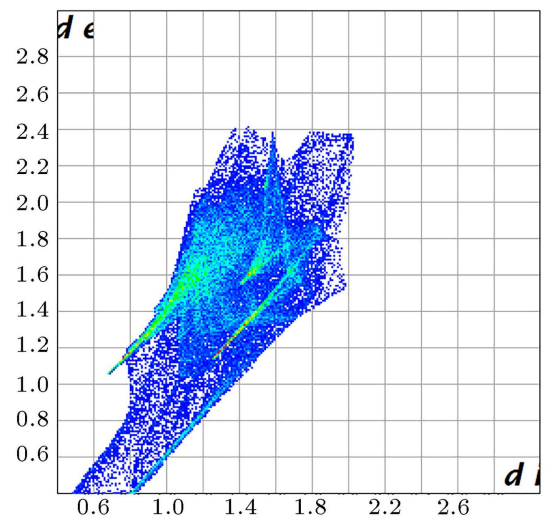

(b)

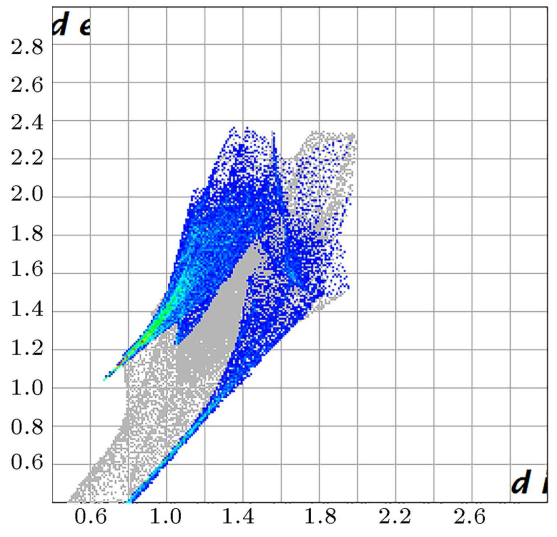

(d)

Figure 5. (a) Hirshfeld surfaces mapped with $d_{\text {norm }}$ for encage potassium ion. (b) Respected fingerprint plot. (c) K...O/O...K highlighted. (d) O...H/H...O highlighted.

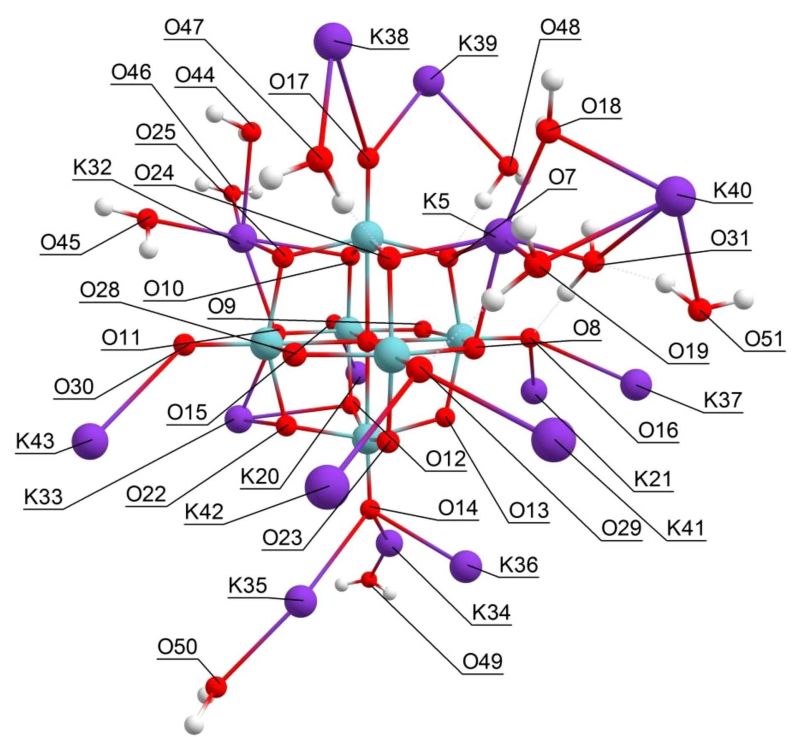

Figure 6. Lindqvist hexaniobate ion with its surrounding atoms.

hexaniobate salt at different $\mathrm{pH}$ values were recorded (Figure 9). All possible hydrogenated structures, i.e., two possible structures for $\left[\mathrm{HNb}_{6} \mathrm{O}_{19}\right]^{7-}$, seven for $\left[\mathrm{H}_{2} \mathrm{Nb}_{6} \mathrm{O}_{19}\right]^{6-}$, and twenty two for $\left[\mathrm{H}_{3} \mathrm{Nb}_{6} \mathrm{O}_{19}\right]^{5-}$, were optimized with the PBE0 functional and the def2-TZVP basis sets in water using the COSMO solvation model $[59,60]$. Structures and their relative energies are summarized in Figure S2 and Table S1 (see Supplementary Information). The lowest energy isomer for each protonation state was chosen for TDDFT calculations. As shown in Figure 9(b), the TDDFT spectra at both $\mathrm{pH}$ values ( 8 and 10 ) agree well with the experimental data.

\subsection{Dye removal process}

The dye removal of $\mathbf{1}$ is evaluated in the color removal of Bismarck brown as a diazo dye pollutant in water under mild conditions. The corresponding color removal efficiency of the dye is calculated using calibration curve (Figure S3 in Supplementary Information) and Eq. (1). From Figure 10, it can be seen that the absorption intensity of the dye decreases as the reaction progresses. These results suggest that compound $\mathbf{1}$ can act as an active catalyst for organic dye removal. In order to investigate the effect of sunlight, the catalytic experiment was repeated in a dark environment as well. The decolorization efficiency was the same, suggesting that sunlight cannot rule out the catalytic process. 
Table 5. Bond critical point electron densities $(\rho)$, their Laplacin $\left(\nabla^{2} \rho\right)$, ellipticities $(\varepsilon)$, and delocalization index for selected bonds in $\mathbf{1}$ and for the encaged potassium.

\begin{tabular}{|c|c|c|c|c|}
\hline Bond & $\rho$ & $\nabla^{2} \rho$ & $\varepsilon$ & $\delta(\mathrm{A} \ldots \mathrm{B})$ \\
\hline $\mathrm{Nb}-\mathrm{O}_{c}$ & 0.456 & 0.167 & 0.002 & 0.536 \\
\hline $\mathrm{Nb}-\mathrm{O}_{b}$ & 0.124 & 0.423 & 0.004 & 1.477 \\
\hline $\mathrm{Nb}-\mathrm{O}_{t}$ & 0.175 & 0.617 & 0.000 & 2.372 \\
\hline $\mathrm{K}_{5}-\mathrm{O}_{7}$ & 0.035 & 0.180 & 0.043 & 0.251 \\
\hline $\mathrm{K}_{5}-\mathrm{O}_{8}$ & 0.036 & 0.182 & 0.038 & 0.212 \\
\hline $\mathrm{K}_{5}-\mathrm{O}_{24}$ & 0.031 & 0.154 & 0.058 & 0.250 \\
\hline $\mathrm{K}_{5}-\mathrm{O}_{18}$ & 0.036 & 0.188 & 0.040 & 0.426 \\
\hline $\mathrm{K}_{5}-\mathrm{O}_{19}$ & 0.035 & 0.187 & 0.059 & 0.439 \\
\hline $\mathrm{K}_{5}-\mathrm{O}_{31}$ & 0.045 & 0.264 & 0.077 & 0.528 \\
\hline $\mathrm{K}_{33}-\mathrm{O}_{11}$ & 0.008 & 0.038 & 0.234 & 0.081 \\
\hline $\mathrm{K}_{33}-\mathrm{O}_{12}$ & 0.025 & 0.088 & 3.822 & 0.153 \\
\hline $\mathrm{K}_{33}-\mathrm{O}_{22}$ & 0.016 & 0.081 & 0.038 & 0.081 \\
\hline $\mathrm{K}_{40}-\mathrm{O}_{18}$ & 0.012 & 0.063 & 0.048 & 0.222 \\
\hline $\mathrm{K}_{40}-\mathrm{O}_{19}$ & 0.009 & 0.044 & 0.331 & 0.153 \\
\hline $\mathrm{K}_{40}-\mathrm{O}_{31}$ & 0.008 & 0.043 & 0.135 & 0.115 \\
\hline $\mathrm{K}_{32}-\mathrm{O}_{10}$ & 0.015 & 0.074 & 0.082 & 0.114 \\
\hline $\mathrm{K}_{32}-\mathrm{O}_{11}$ & 0.022 & 0.115 & 0.038 & 0.168 \\
\hline $\mathrm{K}_{32}-\mathrm{O}_{25}$ & 0.015 & 0.074 & 0.070 & 0.112 \\
\hline $\mathrm{K}_{32}-\mathrm{O}_{44}$ & 0.027 & 0.154 & 0.100 & 0.458 \\
\hline $\mathrm{K}_{32}-\mathrm{O}_{45}$ & 0.023 & 0.116 & 0.043 & 0.381 \\
\hline $\mathrm{K}_{32}-\mathrm{O}_{46}$ & 0.012 & 0.064 & 0.152 & 0.309 \\
\hline $\mathrm{K}_{34}-\mathrm{O}_{14}$ & 0.018 & 0.084 & 0.003 & 0. 247 \\
\hline $\mathrm{K}_{35}-\mathrm{O}_{14}$ & 0.018 & 0.084 & 0.004 & 0.247 \\
\hline $\mathrm{K}_{36}-\mathrm{O}_{14}$ & 0.016 & 0.075 & 0.020 & 0.216 \\
\hline $\mathrm{K}_{35}-\mathrm{O}_{50}$ & 0.014 & 0.074 & 0.126 & 0.380 \\
\hline $\mathrm{K}_{34}-\mathrm{O}_{49}$ & 0.014 & 0.074 & 0.121 & 0.380 \\
\hline $\mathrm{K}_{38}-\mathrm{O}_{17}$ & 0.012 & 0.058 & 0.023 & 0.184 \\
\hline $\mathrm{K}_{38}-\mathrm{O}_{47}$ & 0.014 & 0.069 & 0.056 & 0.292 \\
\hline $\mathrm{K}_{39}-\mathrm{O}_{17}$ & 0.012 & 0.058 & 0.017 & 0.189 \\
\hline $\mathrm{K}_{39}-\mathrm{O}_{48}$ & 0.015 & 0.075 & 0.070 & 0.315 \\
\hline $\mathrm{K}_{20}-\mathrm{O}_{15}$ & 0.012 & 0.056 & 0.009 & 0.217 \\
\hline $\mathrm{K}_{c^{-}}-\mathrm{OH}_{2(\text { Type-1) }}$ & 0.413 & 0.224 & 0.113 & 0.473 \\
\hline $\mathrm{K}_{c}-\mathrm{OH}_{2(\text { Type-2) }}$ & 0.377 & 0.203 & 0.029 & 0.443 \\
\hline $\mathrm{K}_{t}-\mathrm{OH}_{2(\text { Type-1) }}$ & 0.009 & 0.041 & 0.029 & 0.169 \\
\hline $\mathrm{K}_{t}-\mathrm{OH}_{2(\text { Type-2) }}$ & 0.011 & 0.053 & 0.026 & 0.201 \\
\hline
\end{tabular}

Note: $\mathrm{K}_{c}$ : Central potassium ion; $\mathrm{K}_{t}$ : Terminal potassium ion
Table 6. Mayer B.O. and natural atomic charges of the selected bonds and atoms in $\mathbf{1}$ and encaged potassium.

\begin{tabular}{|c|c|c|c|}
\hline Bond & B.O. & Atom & Charge \\
\hline $\mathrm{Nb}-\mathrm{O}_{c}$ & 0.164 & $\mathrm{Nb}$ & 1.64 \\
\hline $\mathrm{Nb}-\mathrm{O}_{b}$ & 0.724 & $\mathrm{O}_{c}$ & -1.04 \\
\hline $\mathrm{Nb}-\mathrm{O}_{b}$ & 0.772 & $\mathrm{O}_{b}$ & -0.90 \\
\hline $\mathrm{Nb}-\mathrm{O}_{t}$ & 1.495 & $\mathrm{O}_{t}$ & -1.00 \\
\hline $\mathrm{K}_{5}-\mathrm{O}_{7}$ & 0.044 & $\mathrm{~K}_{5}$ & 0.89 \\
\hline $\mathrm{K}_{5}-\mathrm{O}_{8}$ & 0.075 & $\mathrm{~K}_{20}$ & 0.99 \\
\hline $\mathrm{K}_{5}-\mathrm{O}_{24}$ & 0.030 & $\mathrm{~K}_{33}$ & 0.97 \\
\hline $\mathrm{K}_{5}-\mathrm{O}_{18}$ & 0.046 & $\mathrm{~K}_{32}$ & 0.95 \\
\hline $\mathrm{K}_{5}-\mathrm{O}_{19}$ & 0.038 & $\mathrm{~K}_{34}$ & 0.97 \\
\hline $\mathrm{K}_{5}-\mathrm{O}_{31}$ & 0.054 & $\mathrm{~K}_{35}$ & 0.97 \\
\hline $\mathrm{K}_{33}-\mathrm{O}_{11}$ & 0.075 & $\mathrm{~K}_{36}$ & 0.97 \\
\hline $\mathrm{K}_{33}-\mathrm{O}_{12}$ & 0.104 & $\mathrm{~K}_{38}$ & 0.98 \\
\hline $\mathrm{K}_{33}-\mathrm{O}_{22}$ & 0.076 & $\mathrm{~K}_{39}$ & 0.98 \\
\hline $\mathrm{K}_{40}-\mathrm{O}_{18}$ & 0.125 & $\mathrm{~K}_{40}$ & 0.99 \\
\hline $\mathrm{K}_{40}-\mathrm{O}_{19}$ & 0.104 & $\mathrm{O}_{7}$ & -1.05 \\
\hline $\mathrm{K}_{40}-\mathrm{O}_{31}$ & 0.080 & $\mathrm{O}_{8}$ & -1.01 \\
\hline $\mathrm{K}_{32}-\mathrm{O}_{10}$ & 0.012 & $\mathrm{O}_{10}$ & -0.90 \\
\hline $\mathrm{K}_{32}-\mathrm{O}_{11}$ & 0.025 & $\mathrm{O}_{11}$ & -1.02 \\
\hline $\mathrm{K}_{32}-\mathrm{O}_{25}$ & 0.010 & $\mathrm{O}_{12}$ & -0.98 \\
\hline $\mathrm{K}_{32}-\mathrm{O}_{44}$ & 0.105 & $\mathrm{O}_{14}$ & -1.16 \\
\hline $\mathrm{K}_{32}-\mathrm{O}_{45}$ & 0.088 & $\mathrm{O}_{15}$ & -0.89 \\
\hline $\mathrm{K}_{32}-\mathrm{O}_{46}$ & 0.072 & $\mathrm{O}_{18}$ & -0.99 \\
\hline $\mathrm{K}_{34}-\mathrm{O}_{14}$ & 0.160 & $\mathrm{O}_{19}$ & -1.04 \\
\hline $\mathrm{K}_{35}-\mathrm{O}_{14}$ & 0.161 & $\mathrm{O}_{22}$ & -0.98 \\
\hline $\mathrm{K}_{36}-\mathrm{O}_{14}$ & 0.147 & $\mathrm{O}_{24}$ & -1.03 \\
\hline $\mathrm{K}_{35}-\mathrm{O}_{50}$ & 0.109 & $\mathrm{O}_{25}$ & -0.91 \\
\hline $\mathrm{K}_{34}-\mathrm{O}_{49}$ & 0.108 & $\mathrm{O}_{31}$ & -1.03 \\
\hline $\mathrm{K}_{38}-\mathrm{O}_{17}$ & 0.128 & $\mathrm{O}_{44}$ & -0.96 \\
\hline $\mathrm{K}_{38}-\mathrm{O}_{47}$ & 0.107 & $\mathrm{O}_{45}$ & -0.98 \\
\hline $\mathrm{K}_{39}-\mathrm{O}_{17}$ & 0.077 & $\mathrm{O}_{46}$ & -0.97 \\
\hline $\mathrm{K}_{39}-\mathrm{O}_{48}$ & 0.117 & $\mathrm{O}_{47}$ & -1.03 \\
\hline \multirow[t]{3}{*}{$\mathrm{K}_{20}-\mathrm{O}_{15}$} & 0.180 & $\mathrm{O}_{48}$ & -1.05 \\
\hline & & $\mathrm{O}_{49}$ & -1.01 \\
\hline & & $\mathrm{O}_{50}$ & -1.01 \\
\hline $\mathrm{K}_{c}-\mathrm{OH}_{2(\text { Type-1) }}$ & 0.112 & $\mathrm{~K}_{c}$ & 0.99 \\
\hline $\mathrm{K}_{c}-\mathrm{OH}_{2(\text { Type-2) }}$ & 0.111 & $\mathrm{~K}_{t}$ & 0.99 \\
\hline $\mathrm{K}_{c}-\mathrm{OH}_{2(\text { Type-2) }}$ & 0.111 & $\mathrm{O}$ & -1.01 \\
\hline $\mathrm{K}_{t}-\mathrm{OH}_{2(\mathrm{Type}-1)}$ & 0.101 & & \\
\hline $\mathrm{K}_{t}-\mathrm{OH}_{2(\text { Type-2) }}$ & 0.105 & & \\
\hline
\end{tabular}




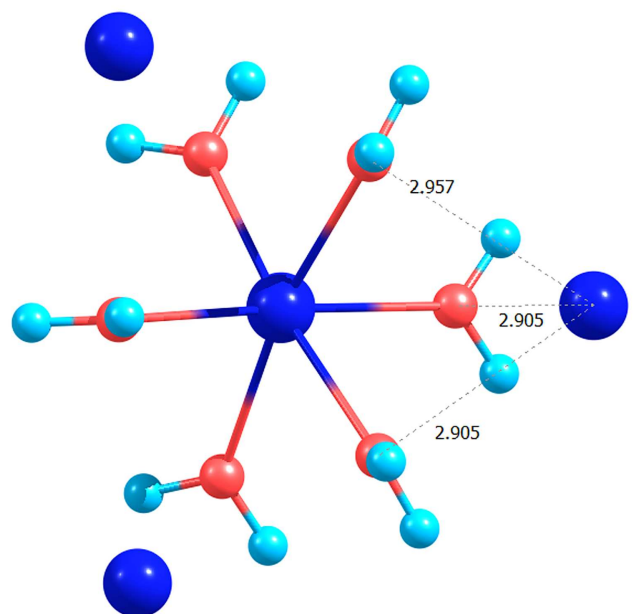

(a)

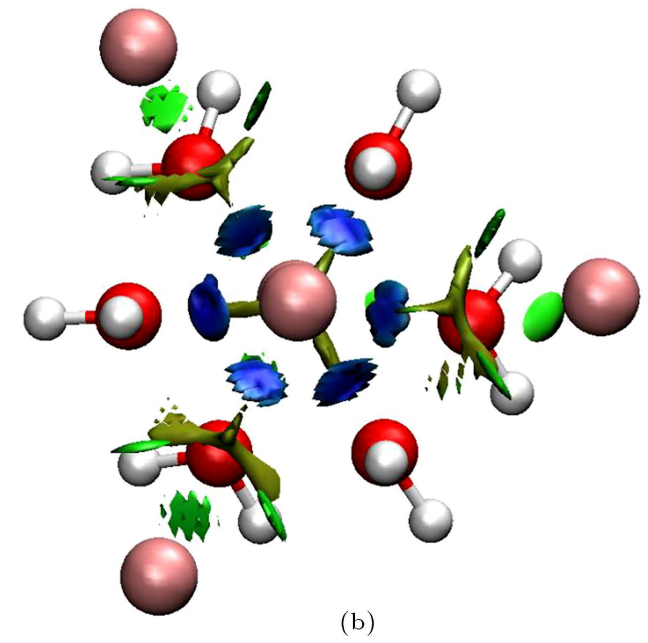

Figure 7. (a) Gradient isosurfaces $(s=0.5)$. (b) Respected RDG plot of encaged potassium.

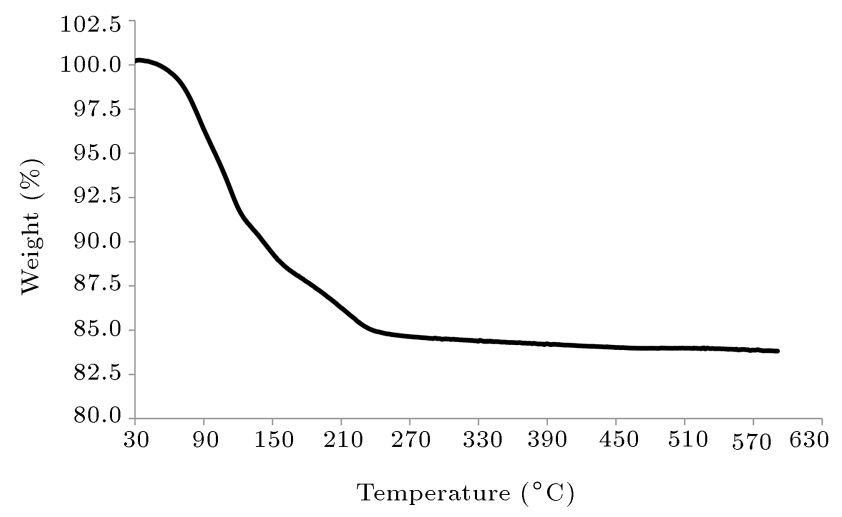

Figure 8. TGA curve of 1 .

Geometry optimization of Bismarck brown structure suggests that the approximate geometric size of the dye molecule is as $17.03 \times 10.26 \times 10.26 \AA$ (Figure $\mathrm{S} 4$ in Supplementary Information). The combination of this result and the packing structure of $\mathbf{1}$ (Figure 2) reveals that cavities in $\mathbf{1}$ are not capable of taking the dye.

In order to study the effect of the catalyst amount on the color removal process, experiments were carried out in the presence of different amounts of the catalysts, while the other variables were kept constant. The results, summarized in Figure 11, show that by decreasing the amount of the catalyst from 30 to $10 \mathrm{mg}$, the decolorization efficiency decreases from 95 to 80 .

The life span of a catalyst is of great importance when considering its industrial applications. Herein, this study examined the catalytic recyclability by recovering and reusing the catalysts for five cycles. After each experiment, the suspensions were centrifuged and the catalysts were separated. The recycled catalysts were washed with acetone and water and, then, were reused in the next catalytic experiment. The decol-

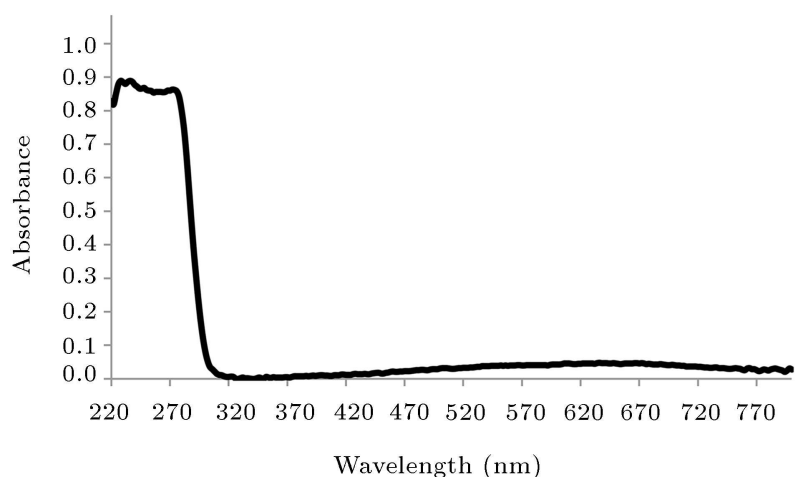

(a)

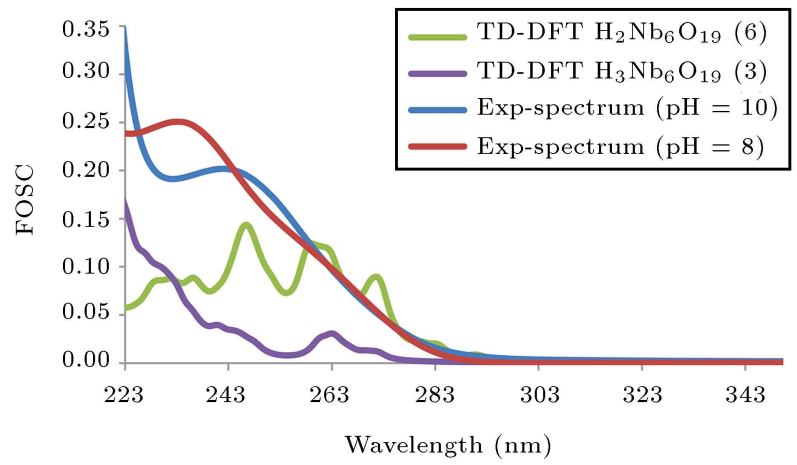

(b)

Figure 9. (a) Solid state UV-visible spectrum of 1. (b) Solution UV-visible spectra of partially protonated $\mathrm{Nb}_{6} \mathrm{O}_{19}^{8-}$ and the related theoretical spectra from TD-DFT calculations.

orization efficiency of the dye in the presence of the recovered catalyst is illustrated in Figure 12(a). It is evident that the catalytic activity of the recycled catalysts remains almost unchanged after five repeated experiments. The PXRD patterns (Figure 13) of the catalysts after and before the catalytic reactions are the 


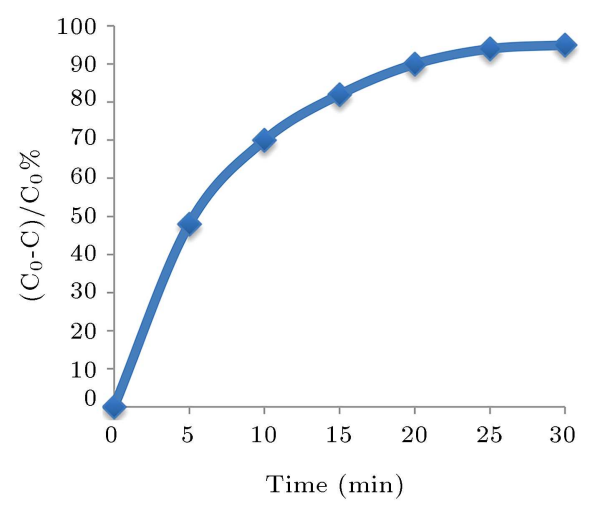

(a)

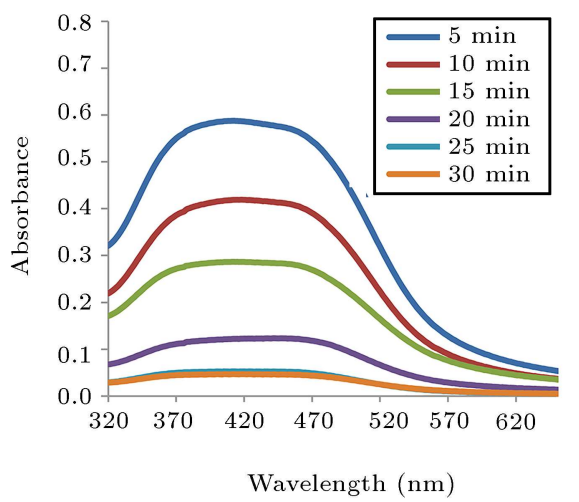

(b)

Figure 10. (a) Color removal activity of 1. (b) UV-Vis spectra of Bismarck brown during the color removal process in the presence of $\mathbf{1}$.

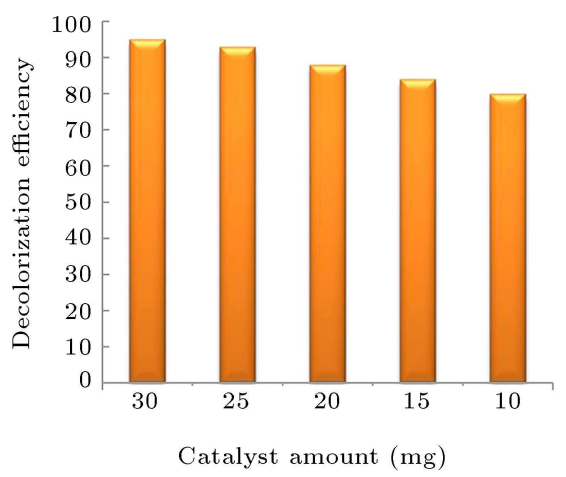

(a)

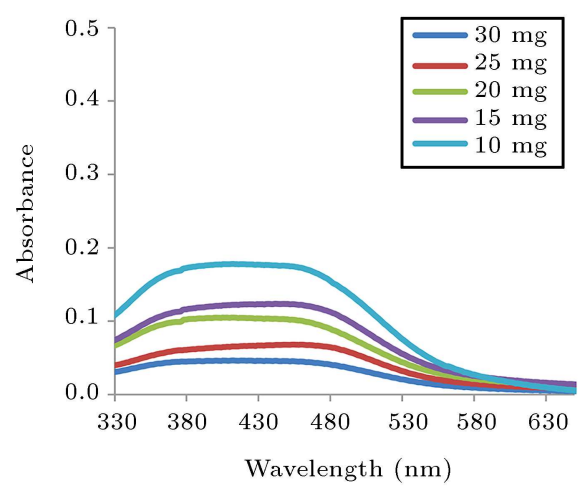

(b)

Figure 11. (a) Decolorization efficiency of Bismarck brown dye using different amounts of the catalysts. (b) UV-Vis spectra of Bismarck brown after 30 min treatment with different amounts of $\mathbf{1}$.

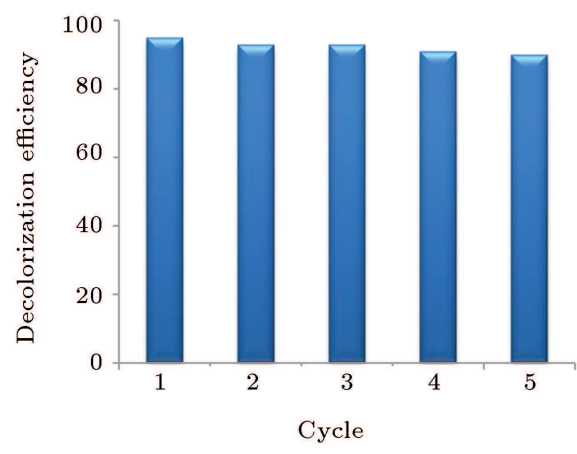

(a)

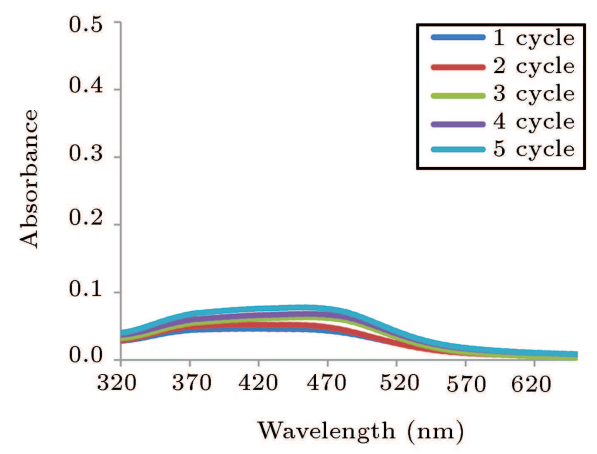

(b)

Figure 12. (a) Decolorization efficiency of Bismarck brown dye using recovered 1. (b) UV-Vis spectra of Bismarck brown after 30 min treatment with recovered $\mathbf{1}$.

same, indicating the stability of the catalysts during the decolorization process.

From Figure 14, it can be seen that the FTIR spectrum of the dye molecule has changed after the dye removal process. The FT-IR spectrum of the Bismarck brown exhibits bands at 875 and $709 \mathrm{~cm}^{-1}$, corresponding to aromatic $\mathrm{C}-\mathrm{H}$ stretching and bending vibrations, respectively. The stretching vibrations of aromatic $\mathrm{C}=\mathrm{C}$ bonds are observed at $1520-1627$ $\mathrm{cm}^{-1}$, and the band at $1242 \mathrm{~cm}^{-1}$ is attributed to the $\mathrm{C}-\mathrm{N}$ stretching vibration. After about $20 \mathrm{~min}$, the intensities of the bands decrease, suggesting the degradation of the dye structure. The Ion Chromatography (IC) analysis of the dye solution after decolorization showed that the dye mineralized into inorganic species such as $\mathrm{NO}_{3}^{-}, \mathrm{NO}_{2}^{-}$, and $\mathrm{Cl}^{-}$indicated the catalytic process of the dye removal (Figure S5 in Supplementary Information). 


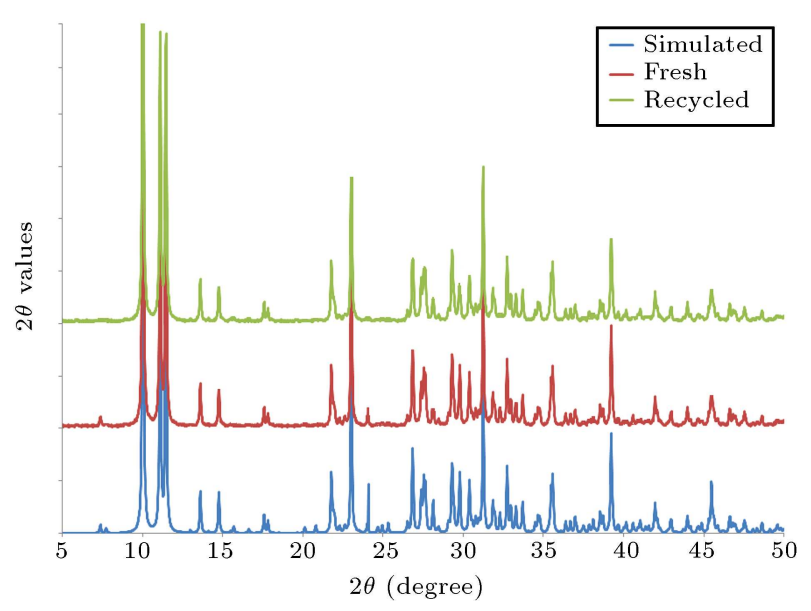

Figure 13. Powder X-ray diffraction patterns of $\mathbf{1}$.

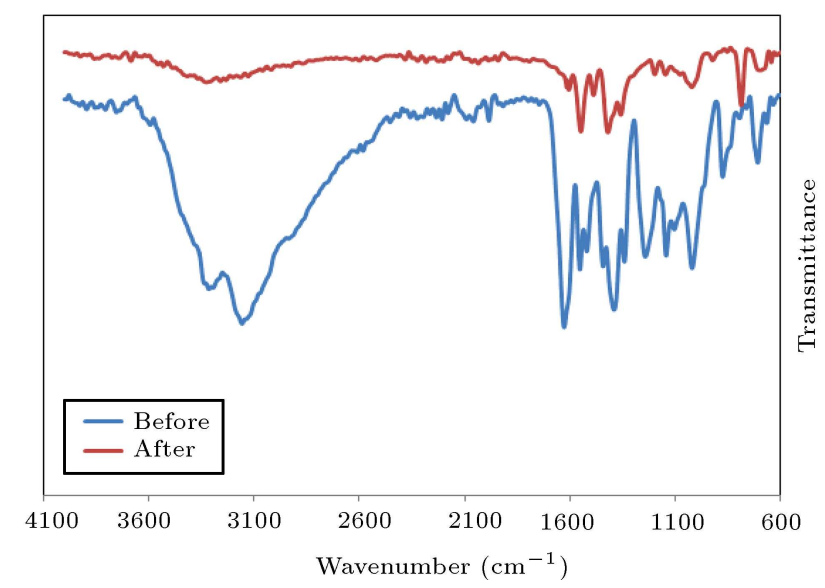

Figure 14. Changes in the FT-IR spectra of Bismarck brown before and after contacting with 1 .

\section{Conclusion}

A novel polyoxoniobate-based 3D framework $\left[\mathrm{K}_{8} \mathrm{H}_{30} \mathrm{Nb}_{6} \mathrm{O}_{31}\right]$ (1) was prepared through the hydrothermal process and characterized by single crystal X-ray diffraction. The structure and properties of $\mathbf{1}$ were fully investigated with various computational methods. The results of these calculations together with thermogravimetric analysis suggested strong interactions among potassium ion, Lindquist hexaniobate, and water molecules, which led to the formation of a 3D niobate framework. It was found that compound $\mathbf{1}$ acted as an efficient catalyst for removing Bismarck brown as a typical diazo dye pollutant in wastewaters. Compound 1 showed good stability during the color removal process and could be easily separated from the aqueous suspension and reused for at least five cycles.

\section{Supplementary Information}

Supplementary Information is available at: http://scientiairanica.sharif.edu/jufile?ar_sfile $=124313$

\section{Acknowledgments}

The authors appreciate the University of Tehran for financial support.

\section{References}

1. Ahuja, S. and Hristovski, K., Novel Solutions to Water Pollution, ACS Publications (2013).

2. Bunzel, K., Kattwinkel, M., and Liess, M. "Effects of organic pollutants from wastewater treatment plants on aquatic invertebrate communities", Water Research, 47, pp. 597-606 (2013).

3. Malaj, E., Peter, C., and Grote, R. "Organic chemicals jeopardize the health of freshwater ecosystems on the continental scale", PNAS, 111, pp. 9549-9554 (2014).

4. Copaciu, F., Opriş, O., and Coman, V. "Diffuse water pollution by anthraquinone and azo dyes in environment importantly alters foliage volatiles, carotenoids and physiology in wheat (Triticum aestivum)", Water, Air, Soil Pollut, 224, p. 1478 (2013).

5. Bafana, A., Devi, S., and Chakrabarti, T. "Azo dyes: past, present and the future", Environ. Rev, 19, pp. 350-371 (2011).

6. Spellman, F.R., The Drinking Water Handbook, CRC Press (2017).

7. Hassaan, M.A. and El Nemr, A. "Health and environmental impacts of dyes: mini review", Am. J. of Environ. Sci. Eng., 1, pp. 64-67 (2017).

8. Chen, S., Zhang, J., and Zhang, C. "Equilibrium and kinetic studies of methyl orange and methyl violet adsorption on activated carbon derived from Phragmites australis", Desalination, 252, pp. 149-156 (2010).

9. Ding, J., Yang, Z., He, C., et al. "UiO-66 ( $\mathrm{Zr})$ coupled with $\mathrm{Bi}_{2} \mathrm{MoO}_{6}$ as photocatalyst for visiblelight promoted dye degradation", J. Colloid Interface Sci., 497, pp. 126-133 (2017).

10. Zhao, H., Xia, Q., Xing, H., et al. "Construction of pillared-layer MOF as efficient visible-light photocatalysts for aqueous $\mathrm{Cr}$ (VI) reduction and dye degradation", ACS Sustain Chem Eng, 5, pp. 44494456 (2017).

11. Crini, G. "Non-conventional low-cost adsorbents for dye removal: a review", Bioresour. Technol., 97, pp. 1061-1085 (2006).

12. Mittal, A., Malviya, A., and Kaur, D., et al. "Studies on the adsorption kinetics and isotherms for the removal and recovery of methyl orange from wastewaters using waste materials", J. Hazard. Mater., 148, pp. 229-240 (2007).

13. Mahmoodi, N., Abdi, M., Oveisi, J., et al. "Metalorganic framework (MIL-100 (Fe)): Synthesis, detailed photocatalytic dye degradation ability in colored textile wastewater and recycling", Mater. Res. Bull, 100, pp. 357-366 (2018). 
14. Baldrian, P., Merhautová, V., Gabriel, J., et al. "Decolorization of synthetic dyes by hydrogen peroxide with heterogeneous catalysis by mixed iron oxides", Appl. Catal., B., 66, pp. 258-264 (2006).

15. Bilal, M., Iqbal, H.M., Hu, H., et al. "Enhanced biocatalytic performance and dye degradation potential of chitosan-encapsulated horseradish peroxidase in a packed bed reactor system", Sci. Total Environ., 575, pp. 1352-1360 (2017).

16. Karcher, S., Kornmüller, A., and Jekel, M. "Anion exchange resins for removal of reactive dyes from textile wastewaters", Water Research, 36, pp. 47174724 (2002).

17. Gemeay, A.H., Mansour, I.A., El-Sharkawy, R.G., et al. "Kinetics and mechanism of the heterogeneous catalyzed oxidative degradation of indigo carmine", $J$. Mol. Catal. A: Chem., 193, pp. 109-120 (2003).

18. Atchudan, R., Edison, T., Perumal, S.I., et al. "Effective photocatalytic degradation of anthropogenic dyes using graphene oxide grafting titanium dioxide nanoparticles under UV-light irradiation", J. Photochem. Photobiol., A., 333, pp. 92-104 (2017).

19. Salama, A., Mohamed, A., Aboamera, N.M., et al. "Photocatalytic degradation of organic dyes using composite nanofibers under UV irradiation", App. Nan. Sci., 8, pp. 155-161 (2018).

20. Roof, I.P., Park, S., Vogt, T., et al. "Crystal growth of two new niobates, $\mathrm{La}_{2} \mathrm{KNbO}_{6}$ and $\mathrm{Nd}_{2} \mathrm{KNbO}_{6}$ : structural, dielectric, photophysical, and photocatalytic properties", Chem. Mater., 20, pp. 3327-3335 (2008).

21. Li, G., Kako, T., Wang, D., et al. "Composition dependence of the photophysical and photocatalytic properties of $\left(\mathrm{AgNbO}_{3}\right)_{1-x} \quad\left(\mathrm{NaNbO}_{3}\right)_{x}$ solid solutions", J. Solid State Chem., 180, pp. 2845-2850 (2007).

22. Xing, J., Tan, Z., Yuan, J., et al. "Structure and electrical properties of $(0.965-x)(\mathrm{K} 0.48 \mathrm{Na} 0.52)$ $\mathrm{NbO}_{3}-x \mathrm{BiGaO}_{3}-0.035(\mathrm{Bi} \quad 0.5 \mathrm{Na} \quad 0.5) \mathrm{ZrO}_{3}$ piezoelectric ceramics", RSC Advances, 6, pp. 5721057216 (2016).

23. Katsumata, K., Cordonier, C.E., Shichi, T., et al. "Photocatalytic activity of $\mathrm{NaNbO}_{3}$ thin films", JACS., 131, pp. 3856-3857 (2009).

24. Oliveira, L., Gonşalves, M., Guerreiro, M., et al. "A new catalyst material based on niobia/iron oxide composite on the oxidation of organic contaminants in water via heterogeneous Fenton mechanisms", Appl. Catal., A., 316, pp. 117-124 (2007).

25. Wang, C., Zhang, M., Stern, B., et al. "Nanophotonic lithium niobate electro-optic modulators", Optics Express, 26, pp. 1547-1555 (2018).
26. Feliczak, A., Walczak, K., Wawrzyńczak, A., et al. "The use of mesoporous molecular sieves containing niobium for the synthesis of vegetable oil-based products", Catal. Today., 140, pp. 23-29 (2009).

27. Dong, J., Hu, J., Chi, Y., et al. "A polyoxoniobatepolyoxovanadate double-anion catalyst for simultaneous oxidative and hydrolytic decontamination of chemical warfare agent simulants", Angew. Chem. Int. Ed., 56, pp. 4473-4477 (2017).

28. Liu, Y., Guo, S., Ding, L., et al. "Lindqvist polyoxoniobate ion-assisted electrodeposition of cobalt and nickel water oxidation catalysts", ACS Appl. Mater. Interfaces., 7, pp. 16632-16644 (2015).

29. Li, L., Niu, Y., Dong, K., et al. "A Ni-containing decaniobate incorporating organic ligands: synthesis, structure, and catalysis for allylic alcohol epoxidation”, RSC Advances, 7, pp. 28696-28701 (2017).

30. Kinnan, M.K., Creasy, W.R., Fullmer, L., et al. "Nerve agent degradation with polyoxoniobates", Eur. J. Inorg. Chem., pp. 2361-2367 (2014).

31. Ge, W., Wang, X., Zhang, L., et al. "Fully-occupied Keggin type polyoxometalate as solid base for catalyzing $\mathrm{CO}_{2}$ cycloaddition and Knoevenagel condensation", Cat. Sci. \& Tech., 6, pp. 460-467 (2016).

32. Xu, Q., Niu, Y., Wang, G., et al. "Polyoxoniobates as a superior Lewis base efficiently catalyzed Knoevenagel condensation", J. Mol. Catal., 453, pp. 93-99 (2018).

33. Zheng, R., Zhang, H., Liu, Y., et al. "Ag-ligand modified tungstovandates and their efficient catalysis degradation properties for methylene blue", J. Solid State Chem., 246, pp. 258-263 (2017).

34. Liu, Y., Zheng, R., Han, Z., et al. "Supramolecular hybrids of polytungstates and their adsorption properties for methylene blue", J. Solid State Chem., 231, pp. 169-174 (2015).

35. Tella, A.C., Olawale, M.D., Neuburger, M., et al. "Synthesis and crystal structure of Cd-based metalorganic framework for removal of methyl-orange from aqueous solution", J. Solid State Chem., 255, pp. 157166 (2017).

36. Yan, J., Zhao, X., Huang, J., et al. "Synthesis and characterization of two polyoxometalates consisting of different $\mathrm{Cu}$-ligand hydrogen phosphate units", $J$. Solid State Chem., 211, pp. 200-205 (2014).

37. Teng, C., Xiao, H., Cai, Q., et al. "Two supramolecular complexes based on polyoxometalates and Co-EDTA units via covalent connection or non-covalent interaction", J. Solid State Chem., 243, pp. 146-153 (2016).

38. Zhang, H., Guo, L., Jiao, J., et al. "Ionic self-assembly of polyoxometalate-dopamine hybrid nanoflowers with excellent catalytic activity for dyes", ACS Sustain Chem Eng., 5, pp. 1358-1367 (2017). 
39. Farhadi, S., Mahmoudi, F., Amini, M.M., et al. "Synthesis and characterization of a series of novel perovskite-type $\mathrm{LaMnO}_{3} /$ Keggin-type polyoxometalate hybrid nanomaterials for fast and selective removal of cationic dyes from aqueous solutions", J. Chem. Soc., Dalton Trans., 46, pp. 3252-3264 (2017).

40. Herrmann, S., Matteis, L., de la Fuente, J., et al. "Removal of multiple contaminants from water by polyoxometalate supported ionic liquid phases (POMSILPs)", Angew. Chem. Int. Ed., 56, pp. 1667-1670 (2017).

41. Santos, I., Loureiro, L., Silva, M., et al. "Studies on the hydrothermal synthesis of niobium oxides", Polyhedron., 21, pp. 2009-2015 (2002).

42. Sheldrick, G.M. "A short history of SHELX", Acta Crystallogr Sect A: Found Crystallogr, 64, pp. 112-122 (2008).

43. Perdew, J.P., Ernzerhof, M., and Burke, K. "Rationale for mixing exact exchange with density functional approximations", J. Chem. Phys., 105, pp. 9982-9985 (1996).

44. Weigend, F. and Ahlrichs, R. "Balanced basis sets of split valence, triple zeta valence and quadruple zeta valence quality for $\mathrm{H}$ to $\mathrm{Rn}$ : Design and assessment of accuracy", Phys. Chem. Chem. Phys., 7, pp. 3297-3305 (2005).

45. Neese, F. "The ORCA program system", Wires Comput Mol Sci., 2, pp. 73-78 (2012).

46. Weinhold, F. and Landis, C.R. "Natural bond orbitals and extensions of localized bonding concepts", Chem Educ Res Pract., 2, pp. 91-104 (2001).

47. Lu, T. and Chen, F. "Multiwfn: a multifunctional wavefunction analyzer", J. Comput. Chem., 33, pp. 580-592 (2012).

48. Spackman, M.A. and Jayatilaka, D. "Hirshfeld surface analysis", CrystEngComm, 11, pp. 19-32 (2009).

49. Hirshfeld, F.L. "Bonded-atom fragments for describing molecular charge densities" , Theor. Chem. Acc., 44, pp. 129-138 (1977).

50. Clausen, H.F., Chevallier, M.S., Spackman, M.A., et al. "Three new co-crystals of hydroquinone: crystal structures and Hirshfeld surface analysis of intermolecular interactions", New J. Chem., 34, pp. 193-199 (2010).

51. Rohl, A.L., Moret, M., Kaminsky, W., et al. "Hirshfeld surfaces identify inadequacies in computations of intermolecular interactions in crystals: pentamorphic 1, 8-dihydroxyanthraquinone", Cryst. Growth Des., 8, pp. 4517-4525 (2008).

52. Parkin, A., Barr, G.J., Spackman, M.A., et al. "Comparing entire crystal structures: structural genetic fingerprinting", CrystEngComm, 9, pp. 648-652 (2007).

53. Spackman, M.A. and McKinnon, J.J. "Fingerprinting intermolecular interactions in molecular crystals", CrystEngComm, 4, pp. 378-392 (2002).
54. Wolff, S., Grimwood, D., McKinnon, J., Jayatilaka, D., and Spackman, M. (2007).

55. Bader, R., The Quantum Theory of Atoms in Molecules, Clarendon Press, Oxford (1990).

56. Matta, C.F. and Boyd, R.J. "An introduction to the quantum theory of atoms in molecules", The Quantum Theory of Atoms in Molecules: From Solid State to DNA and Drug Design, Wiley (2007).

57. Johnson, E.R., Keinan, S., Mori-Sanchez, P., et al. "Revealing noncovalent interactions", JACS., 132, pp. 6498-6506 (2010).

58. Black, J., Nyman, M., Casey, W. "Kinetics of 17Oexchange reactions in aqueous metal-oxo nanoclusters", Geochim. Cosmochim. Acta., 70, p. A53 (2006).

59. Klamt, A. "Conductor-like screening model for real solvents: a new approach to the quantitative calculation of solvation phenomena", J. Phys. Chem., 99, pp. 2224-2235 (1995).

60. Klamt, A. "The COSMO and COSMO-RS solvation models", Wires. Comput. Mol. Sci., 1, pp. 699-709 (2011).

\section{Appendix}

Supporting data CSD 431187 contains the supplementary crystallographic data for complex. These data are available free of charge via www.ccdc. cam.ac.uk/conts/retrieving.html, or from the Cambridge Crystallographic Data Centre, 12, Union Road, Cambridge CB2 1EZ, UK fax: +44-1223-336033; or deposit@ccdc.cam.ac.uk.

\section{Biographies}

Barzin Safarkoopayeh received his MSc from Sharif University of Technology in 2014; currently, he is a PhD Student at University of Tehran. His research interest is synthesis and characterization of new MOFs and investigating their gas adsorption properties and predicting absorption/emission spectra of light emitting diodes using TD-DFT and multireference CASSCF/NEVPT2 computational methods.

Alireza Abbasi received his BSc degree in Applied Chemistry from Sharif University of Technology in 1996; he obtained MSc and PhD degrees in Structural Chemistry from Stockholm University in 2003 and 2005, respectively. He is currently a Full Professor at the School of Chemistry, College of Science, University of Tehran. His research interests include X-ray crystallography, structural chemistry, metal-organic frameworks, nanomaterials and catalysis.

Abdol Hadi Mokarizadeh received his MSc from Chemical Engineering, University of Tehran. During his master's studies, he worked on molecular dynamic 
and Monte Carlo simulations. Currently, he is spending his PhD at University of Akron Polymer Science, USA.

Alireza Shayesteh received a BSc degree from University of Isfahan in 2001 and a $\mathrm{PhD}$ degree from University of Waterloo in 2006. He is currently an Associate Professor of Physical Chemistry in University of Tehran. Moreover, his research interests are molecular spectroscopy and computational chemistry.
Mahnaz Najafi received her BSc and MSc degrees in Pure and Inorganic Chemistry from Alzahra University in 2005 and 2008, respectively. She obtained her $\mathrm{PhD}$ degree in Inorganic Chemistry from University of Tehran in 2015 and, then, undertook post-doctoral research in the field of catalysis in the group of Professor Alireza Abbasi. Her research interests include polyoxometalates, coordination polymers, and nanomaterials as catalysts. 